\title{
RELATIONSHIP BETWEEN HEMATOLOGIC PARAMETERS AND CAROTID INTIMA MEDIA THICKNESS IN
} PATIENTS WITH ACUTE STROKE

\author{
Yılmaz İNANÇ*, Yusuf İNANÇ** \\ *Kahramanmaraş Sütçü İmam University Faculty of Medicine, Department of Neurology, \\ KAHRAMANMARAŞ, TURKEY \\ **Gaziantep University Faculty of Medicine, Department of Neurology, GAZIANTEP, TURKEY
}

\begin{abstract}
INTRODUCTION: Stroke is one of the most important causes of mortality and morbidity worldwide. CIMT is one of the predictors of ischemic stroke and is associated with various risk factors. It was aimed to investigate the relationship between the neutrophil lymphocyte ratio (NLR) and platelet lymphocyte ratio (PLR) and Carotid intima-media thickness (CIMT) in subclinical inflammation markers in ischemic stroke patients.

METHODS: A retrospective evaluation was made of 113 patients with acute ischemic cerebrovascular event and treated with intravenous (IV) thrombolytic therapy. Patients were grouped according to the Oxford Community Stroke Project (OCSP) classification under 4 sub-groups and CIMT was measured. In patients with complete blood counts, NLR was obtained by dividing the number of neutrophils by the number of lymphocytes and PLR by dividing the number of platelets by the number of lymphocytes.

RESULTS: The subgroups were determined as PACI (36.3\%), POCI (32.7\%), TACI (18.6\%) and LACI (12.4\%).

A statistically significant difference was determined in NLR value between the subtypes $(\mathrm{p}=0.004)$. In the POCI group, NLR was higher than in the PACI and LACI groups ( $\mathrm{p}=0.038, \mathrm{p}=0.015$; respectively). In the TACI group, a non-significant correlation was found between NLR and right and left CIMT ( $p=0.234, p=0.250$, respectively) and between PLR and right and left CIMT ( $\mathrm{p}=0.198, \mathrm{p}=0.074$, respectively).

DISCUSSION and CONCLUSION: A significant positive correlation was determined between NLR and CIMT. Similarly, some studies have shown that PLR and carotid stenosis are correlated. There are few studies in literature that examine the distribution of NLR according to OCSP subtypes. Further studies are needed to establish the correlation between CIMT and NLR and PLR in stroke patients.
\end{abstract}

Keywords: Neutrophil, lymphocyte, intima-media thickness.

\section{AKUT İNME GEÇIREN HASTALARDA HEMATOLOJIKK PARAMETRELER İLE KAROTIS İNTIMA MEDİA KALINLIĞI ARASINDAKİ İLIŞKİ}

\section{ÖZET}

GİRIŞ ve AMAÇ: İnme, dünya çapında mortalite ve morbiditenin en önemli nedenlerinden biridir. CIMT, iskemik inmenin belirleyicilerinden biridir ve çeşitli risk faktörleri ile ilişkilidir.İskemik inme hastalarında subklinik inflamasyon belirteçleri nötrofil lenfosit oranı (NLR) ve trombosit lenfosit oranı (PLR) ile karotis intima-media(KIMT) arasındaki ilişkinin araştırılması amaçlanmıştır.

YÖNTEM ve GEREÇLER: Akut iskemik serebrovasküler inem geçiren 113 hasta retrospektif olarak değerlendirildi ve intravenöz (IV) trombolitik tedavi ile tedavi edildi. Hastalar Oxford Toplum İnme Projesi (OCSP) sınıflamasına göre dört alt grupta gruplandırıldı ve CIMT ölçüldü. Tam kan sayımı olan hastalarda, nötrofil sayısının lenfosit sayısına bölünmesiyle NLR ve trombosit sayısını lenfosit sayısına bölerek PLR elde edildi.

BULGULAR: Alt gruplar PACI (\% 36.3), POCI (\% 32.7), TACI (\% 18.6) ve LACI (\% 12.4) olarak belirlendi. Alt gruplar arasındaki NLR değerinde istatistiksel olarak anlamlı bir fark bulundu ( $p=0.004)$. POCI grubunda NLR, PACI ve LACI gruplarından daha yüksekti (sırasıyla $\mathrm{p}=0.038, \mathrm{p}=0.015$ ). TACI grubunda NLR ile sağ ve sol CIMT arasında (sırasıyla $\mathrm{p}=$ $0.234, p=0.250$ ) ve PLR ile sağ ve sol CIMT arasında (sırasıyla $p=0.198, p=0.074$ ) anlamlı olmayan bir ilişki bulundu.

Corresponding author: Yllmaz İnanç Asst. Prof. MD. Sütçü İmam University Faculty of Medicine, Department of Neurology, 46080 Kahramanmaraş, Turkey. Telephone: +903442212348 E-mail: drinancc@gmail.com Received: 30.05.2018 Accepted: 17.07.2018

This article should be cited as following: Inanç Y, Inanc Y. Relationship between hematologic parameters and carotid intima media thickness in patients with acute stroke. Turkish Journal of Cerebrovascular Diseases 2018; 24 (2): 71-77. doi:10.5505/tbdhd.2018.55376 
Inanc et al.

TARTIŞMA ve SONUÇ: NLR ve CIMT arasında anlamlı bir pozitif korelasyon belirlendi. Benzer şekilde, bazı çalışmalar PLR ve karotis stenozunun korelasyon gösterdiğini göstermiștir. Literatürde NLS'nin OCSP alt tiplerine göre dağılımını inceleyen çok az çalışma bulunmaktadır. İnme hastalarında CIMT ile NLR ve PLR arasındaki korelasyonu belirlemek için daha ileri çalışmalara ihtiyaç vardır.

Anahtar Sözcükler: Nötrofil, lenfosit, intima-media kalınlı̆̆ı.

\section{INTRODUCTION}

Stroke is one of the leading causes of mortality worldwide and can cause major morbidity and disability. Of all strokes, $87 \%$ are ischemic stroke, $10 \%$ are intracerebral hemorrhage and $3 \%$ are subarachnoid hemorrhage $(1,2,3)$.

Atherosclerosis is a diffuse degenerative process that results in plaque formation in necrotic cells, lipid and cholesterol crystals, which are more dense in certain arteries, in the involved arteries. These plaques can lead to stenosis, embolism, or thrombosis and play an important role in acute ischemic events (4).

The cells involved inflammation may vary according to the stage and intensity of the inflammatory process. Neutrophils are one of the components of acute inflammation. In recent years, neutrophil/lymphocyte ratio (NLR) and platelet/lymphocyte ratio (PLR) have been added to the parameters which are investigated as inflammatory markers.

These markers have also started to be evaluated frequently in studies carried out in many groups of diseases accompanied by inflammation and autoimmunity (5). Carotid intima-media thickness (CIMT) can be easily measured in a non-invasive, accurate manner in daily practice with high resolution B-mode ultrasound (US) and this provides accurate information on the early findings of atherosclerosis. Mean common CIMT and mean maximum common CIMT are the most frequently used measurement parameters. The risks of cardiovascular disease can be determined by evaluating the changes that occur in CIMT measurements over time $(5,6,7)$.

In this study it was aimed to investigate the relationship between the carotid intima-media thickness and the neutrophil/lymphocyte ratio (NLR) and platelet/lymphocyte ratio (PLR) of the carotid intima-media thickness in the clinical subtypes of patients admitted with acute ischemic cerebrovascular event.

\section{MATERIAL AND METHODS}

An evaluation was made of patients between 2014 and 2016 with acute ischemic cerebrovascular event and treated with intravenous (IV) thrombolytic therapy. The data of a total of 113 patients were retrospectively reviewed. This study was designed as a multicenter, retrospective, observational and crosssectional study. A LOGIQ P5 portable ultrasonography device (GE Healthcare, Buckinghamshire, United Kingdom) with a scan frequency of 5-12 MHz was used to measure the thickness of the carotid intima-media. The average thickness of three bilateral points was obtained using B-mode US. Based on the Oxfordshire Community Stroke Project (OCSP) classification, male and female patients were divided into four groups according to clinically detectable subtypes of cerebral infarction. In all these groups, carotid intima-media thickness (CIMT) was assessed.

Routine blood screening was evaluated during the emergency department visits of the patients. Leukocyte, neutrophil, erythrocyte, and platelet counts were measured as the number of cells in $1 \mathrm{~mm} 3$. Neutrophil, lymphocyte, and monocyte percentages were calculated as the percentage (\%) of the total leukocyte counts of these cells. The neutrophil lymphocyte ratio was calculated by dividing the number of neutrophils by the number of lymphocytes. The platelet lymphocyte ratio was obtained by dividing the platelet count by the lymphocyte count.

In the analyses of the data obtained in the study, SPSS 22.0 (IBM Corparation, Armonk, New York, United States) and PAST 3 (Hammer, Ø., Harper, D.A.T., Ryan, P.D. 2001. Paleontological statistics) programs were used.

Quantitative variables were expressed as mean \pm SD (standard deviation) and median range (Maximum-Minimum), and categorical variables were stated as number (n) and percentage (\%). Variables were examined at $95 \%$ confidence interval and a value of $\mathrm{p}<0.05$ was accepted as statistically significant. 


\section{RESULTS}

A total of 113 patients with acute ischemic stroke were included in the study. The patients comprised $71.7 \%$ males and $28.3 \%$ females, giving a male to female ratio of 2.5/1. The median age of the patients was 63 years (range 23-89 years). The subgroups were determined as PACI (36.3\%), POCI (32.7\%), TACI (18.6\%) and LACI (12.4\%). A significant difference was determined between clinical subtypes in terms of CIMT (carotid intima media thickness).

A higher median CIMT value was determined in patients with POCI compared to those with TACI (median 0.80 vs. $0.14 \mathrm{~mm}$; $\mathrm{p}=0.028$ ) (Table 1 ). In the left carotid artery, there was no difference between clinical subtypes in terms of CIMT. There was no statistically significant difference between the clinical subtypes in terms of mean leukocyte counts. A statistically significant difference was found between the mean neutrophil percentage ratios of the patients and the lymphocyte percentage ratios ( $p=0.011, p=0.004$ respectively). When the clinical subtypes were examined, the percentage of neutrophils in POCI-detected patients was statistically significantly higher than that of LACI patients $(p=0.021)$. The mean lymphocyte percentage was found to be statistically significantly higher in patients with LACI than in patients with POCI $(p=0.007)$. There was no statistically significant difference between clinical subtypes in terms of MPV, erythrocyte count and MCV values ( $\mathrm{p}=0.083, \mathrm{p}=0.271, \mathrm{p}=0.752$; respectively) (Table 1). There was a statistically significant difference between the subtypes in terms of NLR $(p=0.004)$. NLR was higher in patients with POCI who developed PACI and LACI ( $p=0.038, p=0.015$, respectively). A statistically significant difference was found when PLR values were examined between subtypes $(p=0.014)$. The PLR values were statistically significantly higher in patients with POCI than in patients with LACI $(\mathrm{p}=0.018)$ (Table I, Figure).

Table I. The general characteristics of the patients, and the laboratory and imaging findings.

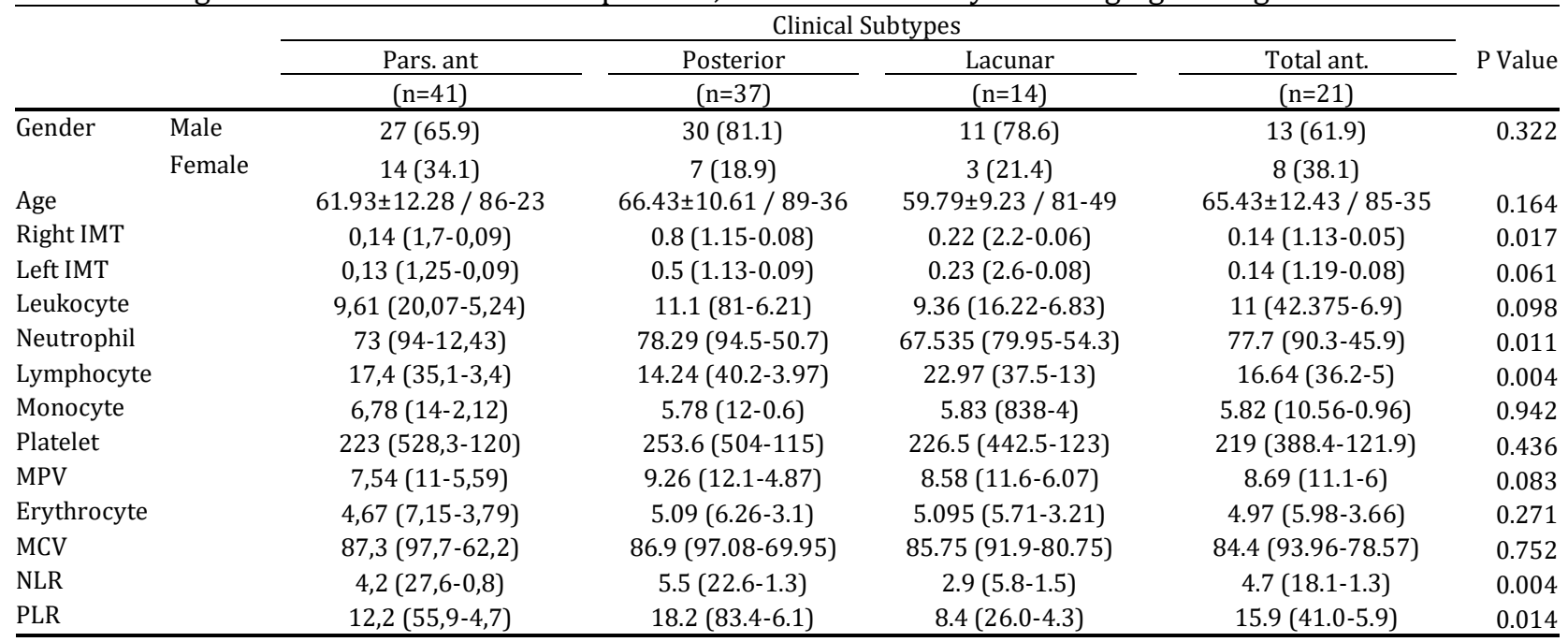

OneWay ANOVA Test - Kruskal Wallis Test - Post Hoc Test : Dunn's Test - Pearson Chi Square Test (Monte Carlo) - Wilcoxon Signed Ranks Test (Monte Carlo)

On a cumulative basis, there was a statistically insignificant positive correlation between NLR and PLR and right and left CIMT (Table II).

In the POCI group, the right CIMT value was found to be statistically significantly higher in female patients (median 0.9 mm; min-max 0.3-1.2 $\mathrm{mm}$ ) compared to male patients (median $0.7 \mathrm{~mm}$; $\min -\max 0.1-1.2 \mathrm{~mm})(\mathrm{p}=0.015)$. However, there was no significant difference between the male and female patients in the other subtypes when the CIMT values were examined (Table II).

A statistically significant difference was found in terms of atrial fibrillation between male $(n=11)$ and female $(\mathrm{n}=3)$ patients in the group of patients with LACI. Atrial fibrillation was not present in the 
majority of male patients $(n=10)$, but all female patients had atrial fibrillation $(n=3)(p=0.011)$. In this patient group, there was no difference in CIMT values between females and males.

Smoking was determined as a risk factor in patients with TOCI $(\mathrm{p}=0.018)$.

No TOCI syndrome was seen in non-smoking females and more than half of the males (53.8\%) with CVE caused by TOCI syndrome were smokers. In There was a statistically significant difference between the four clinical subtypes, regardless of gender, in terms of coronary artery disease. The majority of patients in the PACI, POCI and LACI sub-groups did not have coronary artery disease (58.5\%, 70.3\% and 64.3\%; respectively). In contrast, the majority of patients in the TOCI group had coronary artery disease $(66.7 \%)(p=0.049)$.

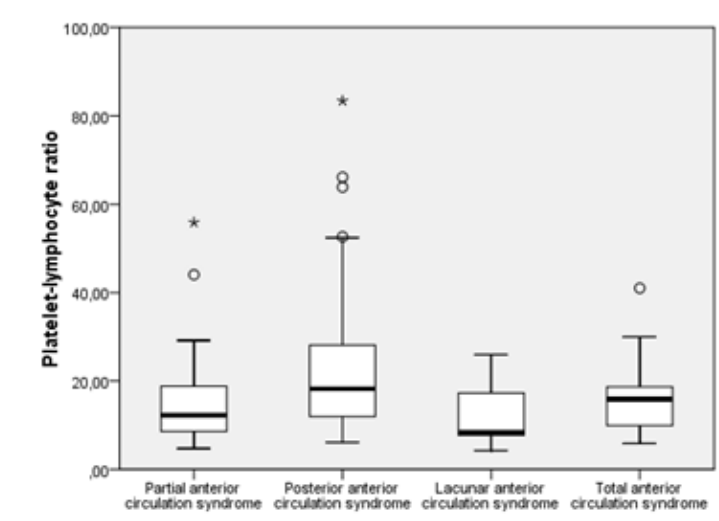

Figure. PLR values in patients with POCI and LACI.

Table II. Comparison between right and left carotis intima media thiskness in subgroups.

\begin{tabular}{llcccc}
\hline \multirow{4}{*}{ Pars. Ant. } & & \multicolumn{2}{c}{ Right CIMT } & \multicolumn{2}{c}{ Left CIMT } \\
& NLR & 0.067 & 0.676 & 0.020 & 0.901 \\
\cline { 2 - 5 } Posterior & PLR & -0.122 & 0.448 & -0.105 & 0.514 \\
& NLR & 0.136 & 0.422 & 0.076 & 0.655 \\
Lacunar & PLR & 0.260 & 0.121 & 0.033 & 0.848 \\
& NLR & -0.267 & 0.356 & -0.317 & 0.270 \\
Total ant. & NLR & -0.254 & 0.382 & -0.317 & 0.270 \\
& PLR & 0.271 & 0.234 & 0.262 & 0.250 \\
Total & 0.292 & 0.198 & 0.398 & 0.074 \\
& NLR & 0.120 & 0.205 & 0.062 & 0.517 \\
& PLR & 0.075 & 0.428 & 0.022 & 0.814 \\
\hline
\end{tabular}

Spearman's rho Test r: Correlation coefficient CIMT:Carotis intima media thickness

\section{DISCUSSION}

The Oxfordshire Community Stroke Project (OCSP) classification is a simple method that is widely used to categorize clinical stroke syndromes (10). According to this classification, patients can be divided into 4 sub-groups: TACI (total anterior circulation infarction), PACI (partial anterior circulation infarction), LACI (lacunar circulation infarction), and POCI (posterior circulation infarction) $(8,9)$. NLR is known to be a marker of subclinical inflammation. Recent studies have suggested that NLR may be a predictor of cardiovascular disease and cancer $(10,11,12)$. In the current study, the highest NLR value was found in the POCI group and the lowest NLR value in the LACI group. To the best of our knowledge, there is a limited number of studies that have investigated NLR values in ischemic stroke patients according to the OCSP subtyping. In a study by Gökhan et al. which compared stroke types, typing was performed according to the criteria of "Trial of Org 10172 Stroke Treatment (TOAST)" and the highest NLR value was determined in stroke type due to LAA and the lowest in cardioembolic stroke type (13).

Several studies in the literature have shown strong links between NLR and CIMT. In a study by Li et al., NLR and CIMT were examined in 320 patients with Type 2 diabetes mellitus and a control group of 250 individuals (14). The CIMT and NLR values were generally high in the diabetic patient group and the NLR values were significantly higher in the diabetic patient group with high CIMT than in the diabetic group with low CIMT $(\mathrm{p}<0.001)$. In our study, in the lacunar infarction group, the NLR value was significantly lower when compared with the other groups $(\mathrm{P}=$ 0.004). Hyun et al. found higher NLR in the high CIMT group in male and female acute and subacute stroke patients $(\mathrm{p}<0.001, \mathrm{p}=0.854$; respectively) (15). As far as we know, no studies have evaluated the relationship between cerebral stroke types and CIMT until the present study. When we evaluated the results in this respect, we found that the CIMT values of the POCI group were significantly higher when compared with the other groups $(p=0.028)$. it was seen that the left CIMT values were similar to the right CIMT values $(\mathrm{P}=0.061)$. but we think that it should be evaluated with prospective studies with more cases since this is not evaluated before in the literature. PLR has been proposed in various studies as a new and simple marker that 
can be used as an indicator of the mediators in thrombocyte-mediated inflammation $(16,17)$. In a study by Altıntaş et al, infarct size and inadequate rate of recanalization were found to be higher in patients with a PLR value of $>145$ (19). However, CIMT values were not evaluated in that study. In the current study comparing PLR values between OCSP stroke subtypes, the PLR value was lowest in the LACI group and highest in the POCI group, with a statistically significant difference determined between these $(p=0.018)$. Cumulatively, there was a non-significant positive correlation between right and left CIMT values and PLR. In the literature, there are few studies which have investigated the relationship between CIMT values and PLR values.

In another study by Altıntaş et al., of 48 patients with paroxysmal atrial fibrillation, high PLR values were seen to be associated with silent brain infarction $(\mathrm{p}<0.001)$ and no significant difference was determined in the carotid ultrasonographic findings between patients with and without silent brain infarction. However, in that study, CIMT values were not given clearly and no correlation analysis was applied between CIMT and PLR. In a study by Soylu et al., 150 patients with carotid artery stenosis were evaluated with CT angiography and were divided into 3 groups according to the PLR values. Carotid artery stenosis was determined at a higher rate in the high PLR group $(p=0.010)(20)$. The PLR value was also correlated with the carotid artery stenosis percentage $(r=0.250, p=0.002)$. In regression analysis, PLR was shown to be an independent variable for descent (Odd's ratio $=1.012, \mathrm{CI}=1.001-1.024, \mathrm{p}=0.031$ ).

In a study involving 140 patients who underwent carotid angiography by Varım et al., the patients were divided into two groups, as those with critical stenosis and those with non-critical stenosis (21). PLR values were statistically significantly higher in the group with critical carotid stenosis $(p<0.0001)$. In that study, carotid Doppler ultrasonography was performed before angiography but CIMT values were not specified and not analyzed.

Cumulatively, PLR has been shown to correlate with atherosclerosis grade, but more studies are needed to compare CIMT and PLR values.

Anemia is known to be a risk factor for ischemic stroke $(22,23)$. MCV is one of the cornerstones in the algorithm of anemia classification. As for other CBC parameters, there have been some studies that have shown a relationship between MCV and carotid stenosis. In the current study, no statistically significant difference was determined in MCV between the OCSP clinical subtypes of ischemic stroke patients. In a study of the association between CIMT values and the parameters of whole blood counts in 2767 asymptomatic patients, Kuo et al. reported higher CIMT values in the group with high MCV in the left carotid artery in male patients ( $p=0.017)(24)$.

There is a limited number of studies in literature that have examined the distribution of CBC parameters in ischemic stroke patients. Hatamian et al. reported that RBC count and MCV values are predictive of mortality in ischemic stroke patients (25). According to the findings of that study, 1 unit increase in MCV reduced mortality in the first week by $6 \%$. The current study is one of a small number of studies using OCSP subtypes to group ischemic stroke patients and which have not shown a relationship between blood parameters and CIMT.

The mean platelet volume (MPV) is a parameter indicating the mean volume of platelets. As large volume platelets contain more granules, they are more reactive than small volume platelets (26). Thus, elevated MPV can be regarded as an indication of increased platelet reactivity. Several studies have investigated the relationship between coronary artery disease, carotid artery stenosis, and peripheral artery disease and MPV.

In the current study, there was no statistically significant difference in MPV between the OCSP subtypes of ischemic stroke patients. In a study by Muscari et al. of ischemic stroke patients, the patients were grouped according to OCSP subtypes and MPV was significantly lower in the LACI group than in the other subtypes $(p=0.04)(27)$. In the same study, MPV values at the time of diagnosis and after 2-6 days were compared and no significant increase in MPV was detected in the LACI group, while a significant increase in MPV was detected in the second sample in the nonlacunar infarct subtypes.

Chen et al. investigated platelet microparticles and MPV values in 112 acute ischemic stroke patients (28). These patients were divided into two groups according to the TOAST classification and MPV was found to be high in both the large artery atherosclerosis (LAA) group and in the small artery occlusion (SAO) group and there was no significant difference. A study of 215 
atherothrombotic stroke patients by Are'valoLorido et al. found a positive association between MPV values and carotid stenosis $(p<0.001)(29)$. MPV was higher in the patient group with more severe carotid stenosis. In a study of 776 acute ischemic stroke or TIA cases, Greisenegger et al showed that high MPV levels were associated with worse outcome scores (30).

Limitation of the study is that OCSP is not a very frequently used classification. We used this classification because the study was retrospective. The low number of cases are limitations to the generalization of the results.

As conclusion; from the results of this study, the highest NLR was seen in the POCI group, and the lowest in the LACI group. To the best of our knowledge, there are few studies which have investigated NLR values in stroke patients according to the OCSP subtype. In the current study, there was no statistically significant correlation between NLR and CIMT in any of the subtypes. Further studies are required on this subject.

\section{REFERENCES}

1. U.S. Centers for Disease Control and Prevention and the Heart Disease and Stroke Statistics - 2007 Update, published by the American Heart Association. Available at http://www.strokecenter.org/patients/stats.html.

2. MacKay J, Mensah GA. World Health Organization. Global Burden of Stroke. The Atlas of Heart Disease and Stroke. Available

http://www.who.int/cardiovascular_diseases/en/cvd_atla s_15_burden_stroke.pdf.

3. Mozaffarian D, Benjamin EJ, Go AS, Arnett DK, Blaha MJ, Cushman M, et al. Heart disease and stroke statistics-2015 update : A report from the American Heart Association. Vol. 131, Circulation. 2015. 29-39 p.

4. Batty JA, Subba S, Luke P, Gigi LWC, Sinclair H, Kunadian V. Intracoronary Imaging in the Detection of Vulnerable Plaques. Curr Cardiol Rep. 2016; 18(3): 1-12.

5. O'Leary DH, Polak JF, Kronmal RA, Manolio TA, Burke GL, Wolfson SK Jr. Carotid-artery intima and media thickness as a risk factor for myocardial infarction and stroke in older adults. Cardiovascular Health Study Collaborative Research Group. N Engl J Med. 1999 Jan 7. 340(1): 14-22.

6. Touboul P-J, Grobbee DE, den Ruijter H. Assessment of subclinical atherosclerosis by carotid intima media thickness: technical issues. Eur J Prev Cardiol. 2012; $19(2$ Suppl): 18-24.

7. Stein JH, Korcarz CE, Hurst RT, Lonn E, Kendall CB, Mohler ER, et al. Use of Carotid Ultrasound to Identify Subclinical Vascular Disease and Evaluate Cardiovascular Disease Risk: A Consensus Statement from the American Society of Echocardiography Carotid Intima-Media Thickness Task Force Endorsed by the Society for Vascular. J Am Soc Echocardiogr. 2008; 21(2): 93-111.
8. Bamford J, Sandercock P, Dennis M, Warlow C, Burn J. Classification and natural history of clinically identifiable subtypes of cerebral infarction. Lancet. 1991; 337(8756): 1521-6.

9. Anderson CS, Taylor B V, Hankey GJ, Stewart-Wynne EG, Jamrozik KD. Validation of a clinical classification for subtypes of acute cerebral infarction. J Neurol Neurosurg Psychiatry. 1994; 57(10): 1173-9.

10. Yang Y, Wang A, Zhao X et al. On behalf of the Thrombolysis Implementation and Monitoring of Acute Ischemic Stroke in China (TIMS-China) investigators. The Oxfordshire Community Stroke Project classification system predicts clinical outcomes following intravenous thrombolysis: a prospective cohort study. Ther Clin Risk Manag. 2016; 12: 1049-1056.

11. Wang J, Jia $\mathrm{Y}$, Wang $\mathrm{N}$, et al. The clinical significance of tumor-infiltrating neutrophils and neutrophil-to- CD8+ lymphocyte ratio in patients with resectable esophageal squamous cell carcinoma. J Transl Med 2014; $12: 7$.

12. Xue P, Kanai M, Mori Y, et al. Neutrophil-to-lymphocyte ratio for predicting palliative chemotherapy outcomes in advanced pancreatic cancer patients. Cancer Med 2014; 3: 406-415.

13. Wang $X$, Zhang G, Jiang $X$, et al. Neutrophil to lymphocyte ratio in relation to risk of all-cause mortality and cardiovascular events among patients undergoing angiography or cardiac revascularization: a metaanalysis of observational studies. Atherosclerosis 2014; 234: 206-213.

14. Gökhan S, Ozhasenekler A, Mansur Durgun H, Akil E, Ustündag $M$, Orak M. Neutrophil lymphocyte ratios in stroke subtypes and transient ischemic attack. Eur Rev Med Pharmacol Sci. 2013 Mar; 17(5): 653-7.

15. Hyun S, Kwon S, Cho S, Park S, Jung W, Moon S, Park J, Ko C, Cho K. Can the Neutrophil-to-Lymphocyte Ratio Appropriately Predict Carotid Artery Stenosis in Patients with Ischemic Stroke?-A Retrospective Study. J Stroke Cerebrovasc Dis. 2015 Nov; 24(11): 2646-51.

16. Köklü E, Yüksel İÖ, Arslan Ş, Bayar N, Çağırcı G, Sarı̈nder Gencer E, Alparslan AȘ, Çay S, and Kuş G. Is Elevated Neutrophil-to-Lymphocyte Ratio a Predictor of Stroke in Patients with Intermediate Carotid Artery Stenosis? Journal of Stroke and Cerebrovascular Diseases, Vol. 25, No. 3 (March), 2016: pp 578-584.

17. Balta S, Demirkol S, Kucuk U. The platelet lymphocyte ratio may be useful inflammatory indicator in clinical practice. Hemodial Int. 2013;17: 668-9.

18. Akkaya E, Gul M, Ugur M. Platelet to lymphocyte ratio: a simple and valuable prognostic marker for acute coronary syndrome. Int J Cardiol. 2014; 177(2): 597-8.

19. Altintas O, Altintas MO, Tasal A, Kucukdagli OT, Asil T. The relationship of platelet-to-lymphocyte ratio with clinical outcome and final infarct core in acute ischemic stroke patients who have undergone endovascular therapy. Neurol Res. 2016 Sep; 38(9): 759-65.

20. Soylu A, Arıkan Cortcu S, Uzunkaya F, Atalay YO, Bekçi T, Güngör L, Belet Ü. The correlation of the platelet-tolymphocyte ratio with the severity of stenosis and stroke in patients with carotid arterial diseaseVascular. 2016 Oct 20. pii: 1708538116673770.

21. Varım C, Varım P, Atılgan Acar B, Vatan MB, Uyanık MŞ, Kaya T, Acar T, Akdemir R. Usefulness of the platelet-tolymphocyte ratio in predicting the severity of carotid artery stenosis in patients undergoing carotid angiography. Kaohsiung J Med Sci. 2016 Feb; 32(2): 86-90. 
22. Biller J, Love BB, Schneck MJ. Ischemic Cerebrovascular Disease. In: Bradley WG, Daroff RB, Fenichel GM, Jankovic J, editors. Neurology in clinical practice: The neurological disorders. 5th ed. Oxford, UK: Butterworth-Heinemann Elsevier; 2008. p. 1165-6, 1169-71.

23. Aminoff MJ. Neurological Complications of Systemic Disease in Adults. In: Bradley WG, editor. Neurology in clinical practice: The neurological disorders. 5th ed. Oxford, UK: Butterworth-Heinemann Elsevier; 2008. p. 1052.

24. Kuo WK, Lee SY, Ma SM, Ling TA, Wu CC. Correlation of hematologic factors to carotid intima-media thickness in men and women: a study of 2767 asymptomatic subjects of Taiwan. Acta Neurol Taiwan. 2012 Dec; 21(4): 158-64.

25. Hatamian H, Saberi A, Pourghasem M. The relationship between stroke mortality and red blood cell parameters. Iran J Neurol. 2014 Oct 6; 13(4): 237-240.

26. Thompson CB, Jakubowski JA, Quinn PG, Deykin D, Valeri CR. Platelet size as a determinant of platelet function. J Lab Clin. Med 1983; 101: 205-213.
27. Muscari A, Puddu GM, Cenni A, Silvestri MG, Giuzio R, Rosati M, Santoro N, Bianchi G, Magalotti D, Zoli M. Mean platelet volume (MPV) increase during acute non-lacunar ischemic strokes. Thromb Res. 2009 Feb; 123(4): 587-591.

28. Chen Y, Xiao Y, Lin Z, Xiao X, He C, Bihl JC, Zhao B, Ma X, Chen Y. The Role of Circulating Platelets Microparticles and Platelet Parameters in Acute Ischemic Stroke Patients. J Stroke Cerebrovasc Dis. 2015 Oct; 24(10): 2313-2320.

29. Arévalo-Lorido JC, Carretero-Gómez J, Villar-Vaca P. Mean platelet volume predicting carotid atherosclerosis in atherothrombotic ischemic stroke. Ir J Med Sci. 2012 Jun; 181(2): 179-183.

30. Greisenegger S, Endler G, Hsieh K, Tentschert S, Mannhalter C, Lalouschek W. Is elevated mean platelet volume associated with a worse outcome in patients with acute ischemic cerebrovascular events? Stroke. 2004 Jul; 35(7): 1688-1691. 